Revue musicale OICRM

revue musicale oicrm

\title{
Dialogues of Cultures
}

\section{French Musical Orientalism in Russia, "Artistic Truth," and Russian Musical Identity}

\section{Adalyat Issiyeva}

Volume 3, numéro 1, 2016

Musique et exotisme en France au tournant du XXe siècle. Altérités recomposées

URI : https://id.erudit.org/iderudit/1060122ar

DOI : https://doi.org/10.7202/1060122ar

Aller au sommaire du numéro

\section{Éditeur(s)}

OICRM

\section{ISSN}

2368-7061 (numérique)

Découvrir la revue

Citer cet article

Issiyeva, A. (2016). Dialogues of Cultures: French Musical Orientalism in Russia, "Artistic Truth," and Russian Musical Identity. Revue musicale OICRM, 3(1), 71-92. https://doi.org/10.7202/1060122ar

\section{Résumé de l'article}

L'influence des Saisons russes, avec son charme tout orientaliste, sur la définition du modernisme français et la culture occidentale en général, est largement connue et abordée par plusieurs chercheurs selon différentes perspectives (Schaeffner 1953, Garafola 1989, Davis 2010, Bellow 2013). Toutefois, peu de travaux se sont penchés sur l'influence des stimuli européens dans l'émergence de l'Orientalisme russe et sur le fait que, à de nombreux égards, son existence est liée à l'Orientalisme français. Tel que l'a déploré le célèbre orientaliste russe Vassili Barthold : « Voisine de l'Orient, la Russie, malgré ce voisinage, préférait souvent la lecture des mauvais livres occidentaux sur l'Orient à l'étude directe de l'Orient » (Bartol'd 1925, p. 295). Ceci résulte des voyages qu'ont effectué, au cours du XIXe siècle, plusieurs littéraires, peintres et linguistes russes en Europe (notamment en France et en Allemagne) pour étudier avec de célèbres orientalistes. Cet article contextualise l'Orientalisme français dans la culture russe du XIXe siècle et considère la façon dont l'Orientalisme musical français a été négocié dans les écrits russes de cette période. Malgré l'opinion critique des musiciens russes eux-mêmes envers la musique française ayant un sujet oriental, la musique a néanmoins trouvé écho dans les pratiques compositionnelles russes et certains de ses dispositifs ont été parfois utilisés pour dépeindre non seulement l'Orient, mais la Russie elle-même.
Tous droits réservés @ Revue musicale OICRM, 2016

Ce document est protégé par la loi sur le droit d'auteur. L’utilisation des services d'Érudit (y compris la reproduction) est assujettie à sa politique d'utilisation que vous pouvez consulter en ligne.

https://apropos.erudit.org/fr/usagers/politique-dutilisation/ 


\title{
Dialogues of Cultures. French Musical Orientalism in Russia, "Artistic Truth," and Russian Musical Identity
}

\author{
Adalyat Issiyeva
}

\begin{abstract}
The influence of the Saisons Russes, with its utterly Orientalist appeal in defining French modernism and Western avant-garde culture in general, is widely known and discussed by many researchers from multiple perspectives (Schaeffner 1953, Garafola 1989, Davis 2010, Bellow 2013). Less emphasised to date is the fact that Russian Orientalism emerged from European stimuli and, in many respects, its very existence is indebted to French Orientalism. As the famous Russian Orientalist Vasily Bartol'd complained, "The Orient's neighbour, Russia, despite its geographical proximity, often preferred reading shoddy Western books on the Orient to a direct study of the Orient" (Bartol'd 1925, p. 295). ${ }^{1}$ This occurred as a result of the nineteenth-century travels of many Russian literary men, painters, and linguists to Europe (notably to France and Germany) to study with famous Orientalists. This paper contextualizes French Orientalism within nineteenth-century Russian culture and considers how French musical Orientalism was negotiated in Russian writings from the period. Despite the critical views of Russian musicians toward French music with oriental subjects, the music nevertheless resonated with Russian compositional practices and some of its devices were used occasionally to depict not only the Orient, but Russia itself.

Keywords: "artistic truth;" nineteenth-century music; Orientalism; Russian-French cultural relationship; Russian self-representation.
\end{abstract}

\section{Résumé}

L'influence des Saisons russes, avec son charme tout orientaliste, sur la définition du modernisme français et la culture occidentale en général, est largement connue et abordée par plusieurs chercheurs selon différentes perspectives (Schaeffner 1953, Garafola 1989, Davis 2010, Bellow 2013). Toutefois, peu de travaux se sont penchés

All translations from Russian are my own except where otherwise noted. 
sur l'influence des stimuli européens dans l'émergence de l'Orientalisme russe et sur le fait que, à de nombreux égards, son existence est liée à l'Orientalisme français. Tel que l'a déploré le célèbre orientaliste russe Vassili Barthold : «Voisine de l'Orient, la Russie, malgré ce voisinage, préférait souvent la lecture des mauvais livres occidentaux sur l'Orient à l'étude directe de l'Orient » (Bartol'd 1925, p. 295). Ceci résulte des voyages qu'ont effectué, au cours du XIX ${ }^{\mathrm{e}}$ siècle, plusieurs littéraires, peintres et linguistes russes en Europe (notamment en France et en Allemagne) pour étudier avec de célèbres orientalistes. Cet article contextualise l'Orientalisme français dans la culture russe du $\mathrm{XIX}^{e}$ siècle et considère la façon dont l'Orientalisme musical français a été négocié dans les écrits russes de cette période. Malgré l'opinion critique des musiciens russes euxmêmes envers la musique française ayant un sujet oriental, la musique a néanmoins trouvé écho dans les pratiques compositionnelles russes et certains de ses dispositifs ont été parfois utilisés pour dépeindre non seulement 1'Orient, mais la Russie elle-même.

Mots clés : "vérité artistique "; musique du XIXe siècle ; Orientalisme ; relations culturelles russo-françaises ; autoreprésentation russe.

\section{INTRODUCTION}

Russian ties with French history and culture are exceptionally rich and diverse. A great passion for French civilisation-which included the cultural phenomenon of bilingualism and the adaptation of images, plots, and motives from French literature and arts-helped determine the special status of French culture in Russian life. A particular niche was carved out for French Orientalism. The purpose of this essay is to contextualize French Orientalism-or more precisely, French artworks with oriental subjects-within nineteenth-century Russian culture, and to consider how French oriental music was received in Russia and resonated with Russian compositional practices. Instead of covering the whole complex phenomenon of Orientalism, described by Edward Said as a theoretical construction designed to serve the interests of European imperial powers, I concentrate on one of its aspects pertinent to nineteenth-century Russia: the role of Orientalism in cultural self-definition (Said 1978). Unlike many Western countries that constructed their national selves in opposition to, or in negation of, the Orient, Russia had a particular relationship with the East, celebrating and even embracing its very difference from the West. Vladimir Stasov, whose writings made his name synonymous with Russian nationalism and the Mighty Five (Moguchaia kuchka, or the Kuchka), identified the "Eastern theme" (vostochnyi element) as one of the four distinguishing features of Russian music. ${ }^{2}$ Still, it is important to acknowledge that Russian Orientalism was not conceived in Russia, but in Europe, and that the first steps in the development of Russian oriental literature and art were made by the followers of French Orientalist schools.

2 The other three elements are skepticism of European tradition, "striving for national character," and "extreme inclination toward program music." See V.V. Stasov, "Dvadtsat'-piat' let russkogo iskusstva. Nasha muzyka," in Vestnik Evropy (1882-1883), reprinted in Sobranie sochinenii (1894, vol. 1, p. 646-698). For an English translation see Weiss and Taruskin (1984, p. 390-394). 
In the course of the nineteenth century, many Russian literary men, painters, and linguists traveled to France to study with famous French Orientalists. The linguists François Bernard Charmoy and Aleksei Boldyrev, who both taught at Russian universities, were trained by the famous French linguist and Orientalist Silvestre de Sacy. Likewise, the famous Russian war artist Vasily Vereshchagin (1862-1904) studied with the great French Orientalist painter and sculptor Jean-Léon Gérôme (1842-1904) at the École des Beaux-Arts in Paris. Some of Vereshchagin's paintings in the Turkestan series resemble Gérôme's works not only in subject matter but also in compositional structure, specific motifs, colours, the manipulation of light and shadow, and scientific attention to ethnographic details. For example, Gérôme's The Doorway to the Mosque El Assaneyn in Cairo where the Heads of the Rebel Beys Were Exposed by Salek-Kachef (1866 ; Figure 1), which depicts extreme brutality and the devalorization of human life, inspired several of Vereshchagin's works that realistically portray not only exotic savagery but also the ruthlessness of Russians in Russian Turkestan (Schimmelpenninck van der Oye 2009). Gérôme's The Doorway to the Mosque portrays an entrance to one of the holiest Islamic sites in Egypt with heads of rebels hanging over the door and tossed in a heap at the doorstep, and two guardians, one of whom sits nearby the pile of heads smoking casually as the second stands on the other side of the door. In his Turkestan series, Vereshchagin borrowed from Gérôme two Orientalist tropes: brutality and indifference to war casualties. Vereshchagin's After Victory (1868), They Rejoice (1872), and Presenting the Trophies (1872; Figure 2) picture severed heads of Russian soldiers in the merciless hands of Asians, while After Failure (1868; Figure 3) portrays a Russian soldier, who smokes indifferently whilst looking at a pile of bodies of Asian warriors. ${ }^{3}$

3 Vereshchagin also left his mark on Gérôme's painting and sculptures. Gérôme's famous The Serpent Charmer (1880) clearly echoes Vereshchagin's The Sale of the Slave-Child (1872): both portray the figure of a naked child at centre, seen from behind; the main protagonists in both works are placed opposite each other; and they share specific design motives on the rugs and walls, and a common color palette. Furthermore, towards the end of his life, Gérôme became interested in Central Asian history and in the 1890s decided to create a sculpture of Tamerlan - the Central Asian conqueror who lived in the fourteenth century. To accomplish this task, the French artist asked Vereshchagin to provide some materials for his work and Vereshchagin sent him photos and various accessories from Russia's Asia, which he believed looked like the subjects from the epoch of Tamerlan (Chernysheva 2014). 




Figure 1: Jean-Leon Gérôme,

The Doorway to the Mosque E1 Assaneyn in Cairo where the Heads of the Rebel Beys Were Exposed by Salek-Kachef, 1866. Oil on panel, $54 \times 43,8 \mathrm{~cm}$. (C) Orientalist Museum, Doha. OM. 184.

Figure 2: Vasily Vereshchagin, Presenting the Trophies, 1872. Oil on canvas, $171,5 \times 240,8 \mathrm{~cm}$. (C) 2015, State Tretyakov Gallery, Moscow.

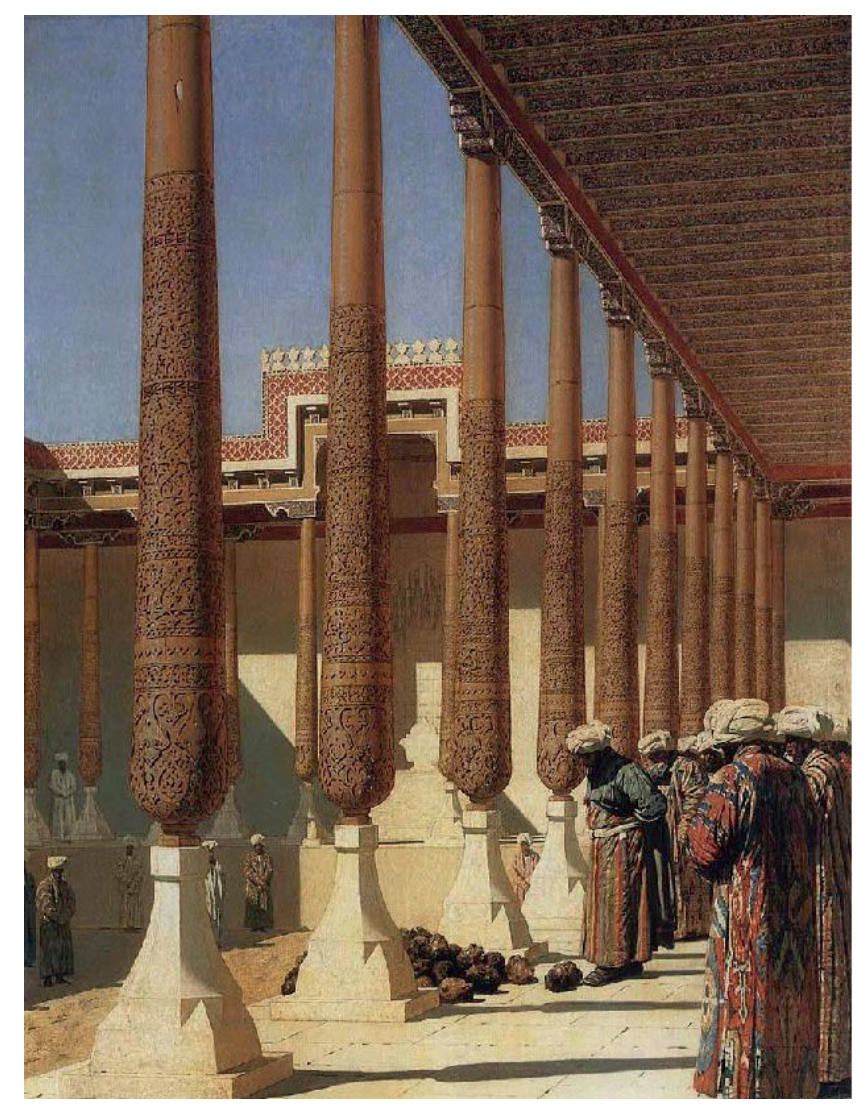




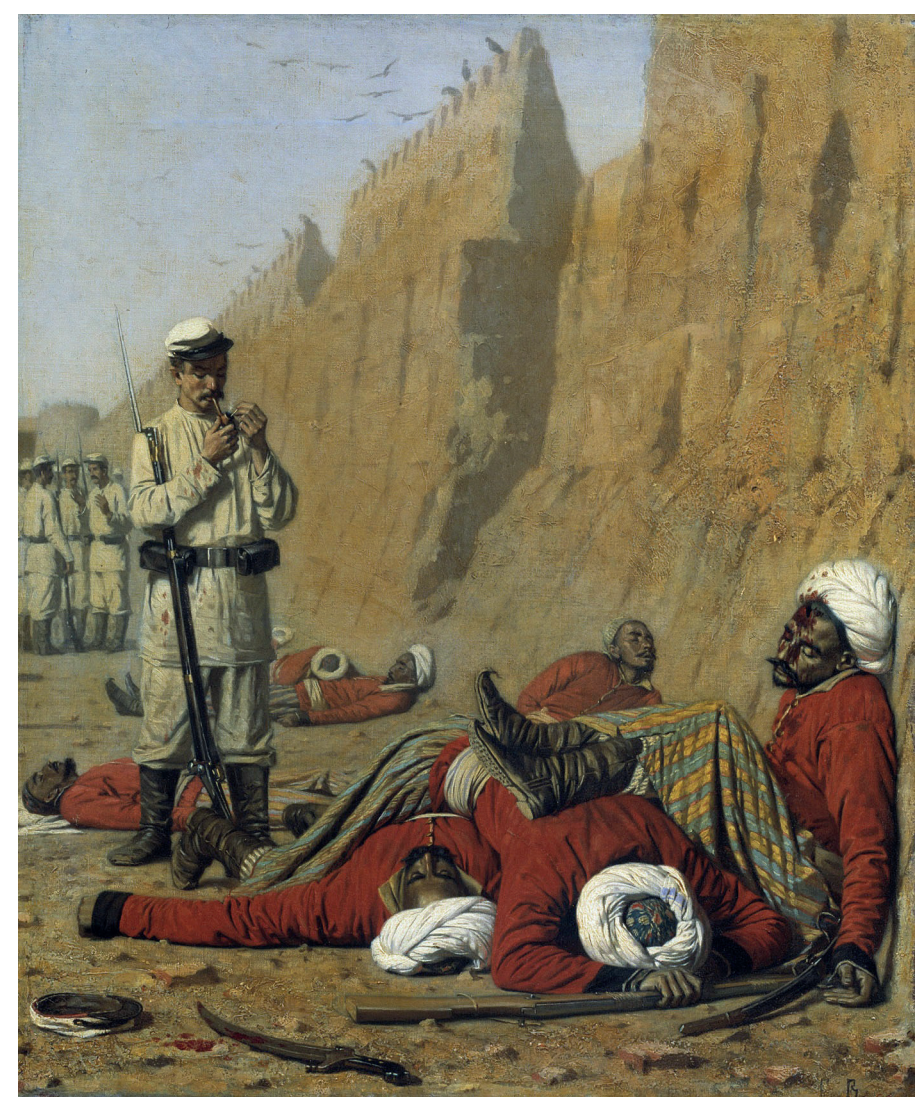

Figure 3: Vasily Vereshchagin, After Failure, 1868. Oil on canvas, $47,5 \times 39,5 \mathrm{~cm}$. (c) 2015, State Russian Museum, Saint Petersburg.

Nineteenth-century Russian architecture also reflected some elements of French Egyptian fashion. ${ }^{4}$ The fascination with everything Egyptian spread in Russia at the time of Alexander I (1801-1825) and reached its peak at the beginning of the twentieth century with the rise of esoteric societies and occultism in Russia (Rosenthal 1997, Solkin 2005). Although until the 1870s there was no Egyptology in Russia, the interest in Egyptian antiquities and a full-scale hunt for ancient treasures was launched at the beginning of the century. ${ }^{5}$ Saint Petersburg Egyptian Museum, from its foundation in 1826, acquired and was granted a number of private Egyptian collections (Carlo Castiglione, August de Montferrand, Countess Alexandra Lavalle, Aleksei Norov) brought from Europe and Egypt. The acquisition of some large collections, such as the one by Milanese amateur orientalist and numismatist Castiglione (comprising more than 1000 objects), was discussed not only in the specialized literature but also in the popular press (S-ii 1825, p. 3).

Egyptian fashion soon appeared in interior furnishings as well as in outdoor structures, such as Egyptian Gates at Tsarskoe Selo (Pushkin), Egyptian Bridge on

4 One of the earliest works on Egyptian architecture was written by Dmitrii Efimov (or Demetrio Jefimoff; 1811-1864), who in the 1830s traveled to Greece and the Middle East (Syria, Nubia, and Egypt), studied and compared architecture of these countries, and presented and published his research in Rome in 1838 (Jefimoff 1838, Struiskii 1840, p. 30-34).

5 On Egyptology in Russia, see "Egiptologiia," in Kim and Shastitko 1990, p. 434-459. 
the Fontanka, and Quay with sphinxes at the Universitetskaya Embankment in Saint Petersburg (see Figure 4). The Sphinxes from the time of Pharaoh Amenhotep III (1390-1352 BC) were purchased and brought from Alexandria in 1832 by the Russian officer and diplomat Andrei Murav'ev. Initially the ancient monuments were located in the courtyard of the Russian Academy of Arts in Saint Petersburg, but in 1834 they were moved to the waterfront of the Neva River in front of the Imperial Academy of Arts (Struve 1912). To complement the architectonics, the Russian architect Konstantin Thon designed the pedestals for the Sphinxes and added columns and griffins to the site.

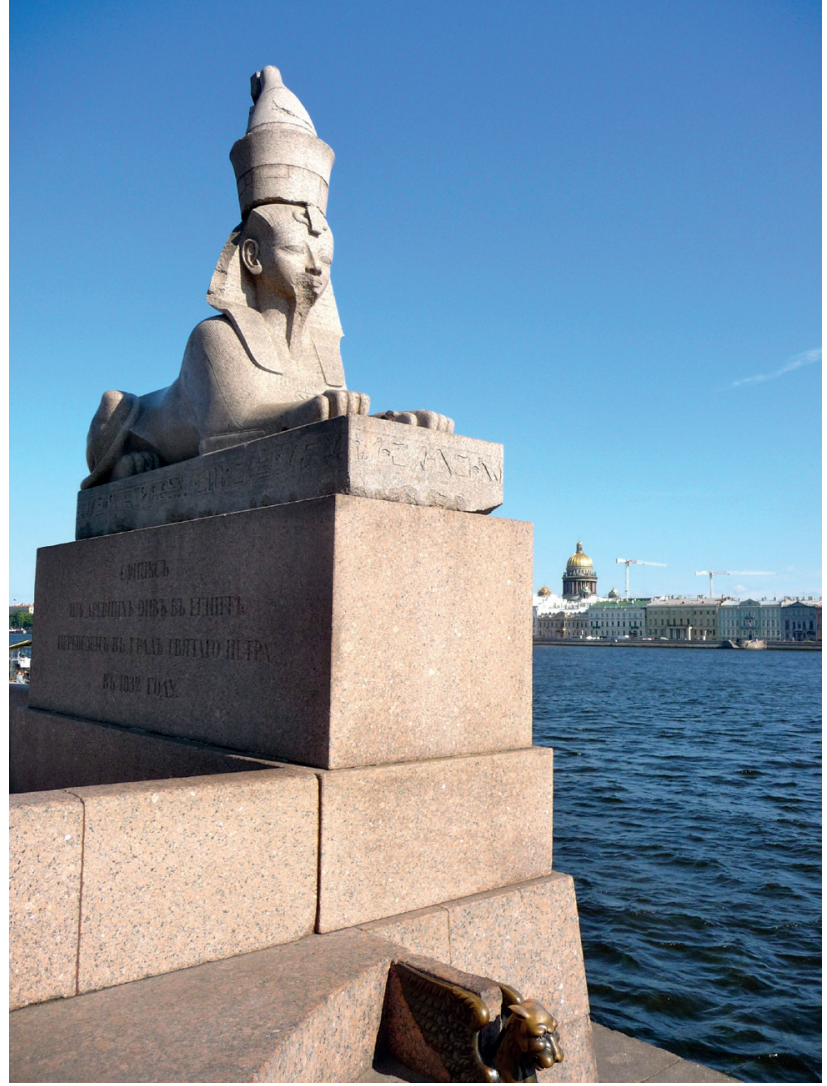

Figure 4: Egyptian Sphinx in front of the Academy of Arts in Saint Petersburg, 2012. Photograph courtesy of Lori McLeese.

Throughout the nineteenth century the French Orientalist culture was imported to Russia by famous French artists and dancers working in Russia. The famous ballet dancer Charles-Louis Didelot (1767-1837), who worked for some 30 years in Saint Petersburg as the Director of the Imperial Theater, created several ballets with oriental subjects, including The Caliph of Baghdad or the Adventures of Young Harum al Rashid, staged in 1818, and Ken-si and Tao or Beauty and the Beast (a full-length Chinese ballet in four acts), staged in 1819 (Swift 1974).

Many Russian poets and writers were also fascinated by French literature about the Orient. Poets Alexander Pushkin and Mikhail Lermontov were nurtured by French classical literature, including Montesquieu's Lettres Persanes and Voltaire's Zaïre (Kondrat'eva 1985). A number of French articles on Arabic and Persian literature written by famous French and European orientalists, notably Simon de Sismondi and Amable Jourdain, were translated and published in nineteenth-century Russian 
journals and inspired Russian writers' inquiries of their own Oriental culture. ${ }^{6}$

Nineteenth-century Russian musicians were similarly swept up with the Western appetite for the Orient and created musical pieces inspired by French oriental sources. Rimsky-Korsakov in his symphonic work Antar, op. 9 (1868), for example, used original Arabic songs from Francisco Salvador-Daniel's Album de Douze Chansons Arabes, Mauresques et Kabyles (Gordeeva 1985, p. 77-79). Later when the composer traveled to Paris to participate in Russian concerts at the 1889 World Fair, he experienced first-hand the French colonialist culture. This event was momentous for Rimsky-Korsakov: it inspired various musical devices used in the Egyptian Scene in his opera Mlada (1889-1890), with a dancer representing Queen Cleopatra. In his memoirs Rimsky-Korsakov recollects:

Of my musical impressions of Paris I shall mention the music in the Hungarian and Algerian cafés, at the Exposition. The virtuoso-playing on the tsevnitsa (Pan's pipe) gave me the idea of introducing this ancient instrument in Mlada during the scene of dance before Queen Cleopatra. At the Algerian café, in the dance of a little girl with the dagger, I was captivated by the sudden blows struck by a Negro on the large drum at the dancer's approach. This effect too I borrowed for the Cleopatra scene. [...] The final impulse was given by the idea of introducing on the stage, in the scene of Cleopatra's dances, an orchestra consisting of Pan's pipes, lyres glissando, a large drum, small clarinets, etc. The outline of Mlada grew by the hour, not by the day, and was finished by September (Rimsky-Korsakov 1935, p. 256-257).

Despite the fact that the Russian interest in the Orient was instigated by French Orientalist culture, throughout the nineteenth century and particularly towards the beginning of the twentieth century, many Russian artists expressed their critical, if not negative, view of French Orientalism. In the introduction to a catalogue of her works displayed at a Moscow exhibition in 1913, the Russian avant-garde artist and painter Natalia Goncharova commented on the shift in her artistic path:

As I set out on my path, I learned the most from contemporary French artists. They opened my eyes, and I grasped the great meaning and value of the art of my homeland, and through it the great value of the art of the East... Now I shake the dust off my feet and distance myself from the West, regarding its levelling significance as utterly petty and insignificant; my path leads to the first source of all art, the East. The art of my homeland is incomparably deeper and grander than anything that I know in the West (Goncharova 1913, cited in Petrova 2002, p. 291).

This statement, which reflects the sentiments of many Russian fin-de-siècle artists, brings up a number of questions concerning Russian self-identification in art, the

6 Amable Jourdain (1815) and Simon de Sismondi (1818). It is significant that Russians were acquainted with the "One Thousand and One Nights" also through Antoine Galland's French translation. 
Russian-French cultural relationship, and Russian artists' understanding of the oriental subject. In the next two sections I will consider nineteenth-century Russian discourses on French music and demonstrate that, despite harsh criticism, French musical Orientalism participated in the formation of Russian musical identity: a number of diverse musical elements associated in France with oriental subjects resonated in Russian music that represented Russia. What follows is not a history of Russian-French artistic, cultural, or musical connections, and will not attempt to engage with the entire vast and heterogeneous repertoire of Russian and French music. Instead it explores how French Orientalism contributed to the emergence and popularization of Orientalism and nationalism in Russia.

\section{Russian Musicians on French Musical Orientalism}

Apart from the works of Berlioz, which were revered, French music generally drew quite a mixed reception in Russia. Many Russian composers did not highly rank French music with oriental subjects. Alexander Sergeevich Dargomyzhsky, after attending a Parisian concert in late 1844 with Félicien David's Le Désert (1844) on the program, criticized it as "unoriginal." In an open letter published in 1845 in Northern Bee, Dargomyzhsky described his experience of listening to David's famous symphonic ode:

Now, I have just returned from a great musical celebration. All Paris was gathered at the Théâtre des Italiens to listen to works by Félicien David, a new French composer, who, all the journals proclaimed in advance to be a Second Beethoven. The most important piece that attracted everyone was a symphony called Le Désert with chorus and soloists, Arabic lyrics, and French verses [...]. The French were wild with delight... One cannot deny David some talent, but he is as much Beethoven, as my thumb [figa] is the Vendôme Column... [on Le Désert:] In general the music is written correctly, and has enough [musical] thoughts, although unoriginal ones. But, despite the fact that David went to the Orient to find melodies for this symphony, I found so little Arabic spirit and so much of French fluff that it [the symphony] should be called Les Boulevards de Paris. And the Arabic song in this symphony reminded me terribly of the [Russian] song Ivan-muzhik (Dargomyzhsky 1952, 1, p. 29-30).

Leaving aside Dargomyzhsky's ironic tone, one can observe that in this passage the Russian composer identifies what he considers to be an inadequate depiction of the Orient in Le Désert: David's Orient remains unconvincing because the French composer did not convey "Arabic spirit." Unfortunately, Dargomyzhsky did not reveal his criteria for "Arabic spirit," that is, how the spirit could be translated into musical terms and how one would distinguish Arabic musical spirit from any other national musical spirit.

Another two citations by Alexander Serov about the same piece provide more details on music and what was considered valuable (or worthless of attention) in music representing the Orient. In a letter to Vladimir Stasov from May 1845, he wrote: 
I am sending you absolute rubbish by Félicien David. As you will see, there is no need to waste any words on it. But for me-I'll confess to you-it is absolutely incomprehensible that Berlioz, with his knowledge of music, would praise such a worthless piece. Compared to David, our Dargomyzhsky is almost Mozart (not to mention Glinka). The "Marche de la Caravane" is more tolerable than everything else (though rather dumb and intolerably repetitive) and the "Lever de Soleil" before the "Chant du Muezzin" bearable (but still so vulgar, so ordinary) (Serov 1962, 1, p. 275). ${ }^{7}$

A decade later, when Serov wrote a review of a concert which included David's Le Désert, his opinion of the piece improved slightly. He praised David's "effective arrangement" of the original sources (the "Marche" from the first part), freshness of orchestral effects (the "Lever de Soleil" in the last part), and oriental character present throughout the piece.

Serov even went so far as to claim that there were some similarities between the French piece and Russian music. He argued that the melody from Ratmir's aria in act three of Glinka's opera Ruslan and Lyudmila (1842) and the melody sung by the tenor in "La Rêverie du Soir" from the second part of David's Le Désert were absolutely identical. However, not surprisingly, Serov preferred the Russian composer, acclaiming his compositional technique and originality. According to him, the comparison of the treatment of the same melody by the different composers was indicative of their respective musical talent:

The French composer left the motive very monotonous: the rhythmic and harmonic rendition is rather flat over the continuous orchestral pedal, which becomes really irritating from its continuous usage... In [Glinka's] Ruslan this melody is tenderly depicted in refined contours and strikes with its beauty and originality of harmonization, which changes continuously and charmingly, like patterns of a kaleidoscope (Serov 1892, 1, p. 465).

These two quotations of Serov suggest a few interesting conclusions. First, despite the originality of musical material brought from a French colony and used by David, the Russian composer's approach to similar material is superior due his effective technique and mastery of compositional skill. Second, a good composition should not consist of too many repetitions, as they might imperil a piece with monotony. Third, orchestral pedals (or pedal points) might make music become "really irritating" if they are not highlighted with different rhythm and harmony.

Vladimir Stasov also added his voice to those disapproving of music with an oriental subject created by French and, more generally, European composers. In his celebrated essay "Twenty-Five Years of Russian Art" (1882) - the same essay that claimed the Eastern element as one of the four most important features of musical

7 In his later article published in 1857 on opera production in Paris, Serov claimed: "Paris loves only rude effects, but understands too little in musical beauty" (Serov 1987, 3, p. 126). 
Russianness - Stasov declared that the "few attempts made by Mozart, Beethoven, Weber, and a few others who wrote pieces alla turca, to create something in the Oriental vein, have testified to [...] their lack of success." After critiquing the East created by German-speaking composers, Stasov turned to the French school and pronounced a fairly harsh judgement of David's Le Désert:

Félicien David [1810-1876, French composer] actually spent some time in the East and introduced a few genuine Oriental melodies into this symphonic ode Le Désert, even occasionally capturing a genuine Oriental flavour. But he was not very talented and produced nothing of lasting importance (Stasov 1883, translated in Weiss and Taruskin 1984, p. 393).

Stasov strongly believed that Russian composers surpassed the French in creating "distinct and vivid" representations of the East because they had been "surrounded all their lives with impressions of the Orient" (ibid.). ${ }^{8}$ Here Stasov made an obvious overstatement: until the end of 1880s, Russian composers had very limited access to musical "impressions of the Orient" unless they traveled to the Caucasus (like Mikhail Glinka or Mily Balakirev) or were exiled to the cities bordering Russia's Asia (like Alexander Aliab'ev). ${ }^{9}$ Most Russian ethnographies written before 1880s provided a scant number of transcriptions of songs from Russia's Asian lands. ${ }^{10}$ Apart from Balakirev, who was a great source of ethnographic material, Russian composers' thirst for an exotic and oriental could be satisfied only by occasional Russian amateur musician-travelers and just a few European publications of songs transcribed in the French colonies. ${ }^{11}$

Established early in the century, Russian composers' and critics' low opinion about French music (including music with oriental subjects) remained unchanged until the end of the nineteenth century. In a conversation with Yastrebtsev and Trifonov in the early 1890s, Rimsky-Korsakov expressed his utterly negative opinion of French music. Yastrebtsev described this conversation as follows:

8 Stasov's statement is hardly surprising: he strongly believed that the Russians shared common past with the peoples of the East and that many elements of Russian culture, including ancient epic literature and decorative art, were borrowed from Russia's Asian neighbours. See Stasov, "Proiskhozhdenie russkikh bylin," in Sobranie sochinenii (1894, 3, p. 948-1260); Stasov, "Russkii narodnyi ornament," in Sobranie sochinenii $(1894,1$, p. 185-213).

9 In my $\mathrm{PhD}$ dissertation I explore at length a number of works by Russian composers who incorporated into their music folk tunes transcribed from Russia's Asian neighbours. In the nineteenth century, Aliab'ev and Balakirev were particularly interested in collecting music materials from Russia's Asian peoples when they traveled to the outskirts of Russia's eastern and southern boarders. Other nineteenth-century Russian composers, such as Rimsky-Korsakov and Alexander Borodin, mostly relied on ethnographic materials brought by Balakirev or on transcriptions published in Russian and European sources (Issiyeva 2013 ).

10 See chapter two, three, and four of my dissertation.

11 Among the transcriptions and arrangements that Russian composers used in their music were Alexandre Christianowitsch's Esquisse historique de la musique arabe (1863) and Salvador-Daniel's Album de Douze Chansons Arabes, Mauresques et Kabyles (1865). 
After tea, the conversation turned to Cui's Quartet, a work which RimskyKorsakov does not like, he said, because it contains more traces of Cui's 'French style' than anything else of his, that is, "the most undesirable Cui!" This brought us to the subject of "the French," for whom Rimsky-Korsakov has so little love. "Those endless $2 / 4$ quadrille motives," he remarked. "The customary little can-can hidden beneath a mask of exquisite harmony and excellent, though purely superficial orchestration. The exception, of course, is Berlioz, whose orchestration is woven out of poetic tonal ideas (Yastrebtsev 1985, p. 34). ${ }^{12}$

Ironically, Cesar Cui, a Russian composer critiqued by his friends as the most French, also expressed a very negative view of French music in general. In his article on different operatic styles from 1864, Cui wrote:

In the French school one is unpleasantly struck by the coldness and lack of passion of the music. In comic opera almost all motives are dance-like, piquant and chic; they are often sweet and gracious; an abrupt rhythm plays the most important role; in serious opera the music is pompous and stilted; but do not try to find in any of these operas either soul or emotion (Cui 1952, p. 34).

Thirty years later, Cui still found French music unattractive, but this time it is was due to the growing fashion of creating sound effects. In his article written in 1894, he claimed that modern French composers, including Camille Saint-Saëns, Vincent d'Indy, and Alfred Bruneau, were creating decadent music since they could no longer develop a musical idea. The cult of the sound (including different orchestral sound effects), according to Cui, replaced the cult of music (or musical ideas) and disguised the true poverty of many French composers' musical creativity. Even those who possessed "wonderful musical technique," like Saint-Saëns, created music that was still "cold and poor in terms of melodic creativity." Others, such as d'Indy and Bruneau, "attain originality only with mechanical devices: after composing the most ordinary music, they add some incidental sharps and flats in front of some incidental notes; it results in music that sounds ugly and out of tune, but original nonetheless" (ibid., p. 423).

Rimsky-Korsakov's and Cui's contemporary_Pyotr Tchaikovsky_also sometimes made unflattering comments about French composers; in particular, he did not like Saint-Saëns' Orientalist operas Princesse Jaune (1872) and Samson et Dalila (1877). ${ }^{13}$ However, the French music that he admired outweighed the works that he did not appreciate. Among Tchaikovsky's favorite composers were George Bizet and Jules

12 Eight years later, Rimsky-Korsakov reiterated his low opinion on French music by saying to Yastrebtsev: "I have recently come to the conclusion that the French of today have completely forgotten how to write beautifully. Both Charpentier's Louise and Saint-Saens' Les Barbares are very bad" (Yastrebtsev 1985, p. 295).

13 See Tchaikovsky's letter to von Meck, 24 February 1883 (Tchaikovsky 1934-1936, 3, p. 157). 
Massenet. Tchaikovsky considered Bizet's Carmen (1875) "the most outstanding operatic work of our time" and called it a "chef-d'oeuvre in the truest sense of the word." 14 He also loved Massenet's oratorio Marie Magdeleine (1871-1872) and his opera Le Roi de Lahore (1876). In a letter to his brother, Modest, Tchaikovsky described that his discovery of Marie Magdeleine was accompanied by an emotional outburst and delightful tears; then he claimed: "No, decisively, the French took the lead in music." ${ }^{15}$ One of his remarks on Massenet's Le Roi de Lahore is particularly interesting, as it reveals what exactly he appreciated in this French Orientalist opera. In a letter addressed to Mme von Meck, Tchaikovsky confessed that Le Roi de Lahore captivated him by the "extraordinary charm of its texture, its simplicity and at the same time its freshness of style and ideas, melodic richness, and especially its graceful harmony." 16

In addition to Tchaikovsky, Rimsky-Korsakov also admitted-although near the end of his life-that he appreciated some musical devices used by French composers. Saint-Saëns, for example, "fully satisfied" him "as an orchestrator" (Yastrebtsev 1985, p. 268). Besides Saint-Saëns, Rimsky-Korsakov also shared with Yastrebtsev his thoughts about Paul Dukas's L'Apprenti Sorcier (1897): "In terms of orchestration, I think he outshines all of us and, surprisingly, his music is relatively free of rubbish" (ibid., p. 376). But probably the most striking and puzzling comment about French music was made by Rimsky-Korsakov just one year before his death. In a 1907 conversation with Yastrebtsev, Rimsky-Korsakov claimed that some French and Russian composers pursued essentially the same musical objectives:

"In a certain sense Saint-Saëns and even Massenet are 'kuchkists," he continued. "What is more, Tchaikovsky's Queen of Spades also conforms to the principles of the 'kuchka.' And these principles are the following: (1) an intelligible and interesting libretto, (2) artistic truth, and (3) intelligent utilization of all the rich resources of today's orchestra and harmony, while at the same time giving primary importance to the voice" (ibid., p. 415).

If accurate, Rimsky-Korsakov's words deserve more than passing comment since they suggest the extent to which late Rimsky-Korsakov dissociated himself from Russian nationalist ideologies. Indeed, his musical ideals were universalist at heart. The first point is concerned with music's subject and does not refer to any national or historical source. The last point emphasizes the importance of an intelligent use of orchestra, harmony, and melody - the elements that many French or European composers also considered the most significant. The second point-on "artistic truth"-is less clear and rather elusive. What is "artistic truth" and does it change

14 See Tchaikovsky's letter to M.I. Tchaikovsky, 18 July 1880 (Tchaikovsky 1955, p. 252).

15 Ibid., p. 254.

16 See Tchaikovsky's letter to Nadezhda von Meck, 20 January 1879 (Tchaikovsky 1959-1971, 8, p. 58). Tchaikovsky also expressed his admiration of French music. In a letter written to his brother, Modest Tchaikovsky, he wrote: "I bought Le Roi de Lahore by Massenet and play it with great pleasure. Damn it, these French have so much taste, chic!" (ibid., 7, p. 484). 
from one national school to another? How can one apply this concept to oriental music? And what kind of devices help to attain it?

\section{“Artistic Truth," French Orientalism, and Russian Self-Representation}

The English "truth," French "vérité" or German "Wahrheit," can be translated into Russian with two different words that enclose two interrelated but semantically distinct concepts: 1) pravda or "factual truth", and 2) istina or "putative truth." 17 Dal', in his Dictionary of the Great Living Russian Language, defines istina in opposition of lozh, or lie, as "everything that is faithful, true, right, and just" (vse chto verno, podlinno, tochno, spravedlivo), while pravda denotes "verisimilitude, fairness, justice, rightness" (pravdivost', spravedlivost', pravosudie, pravota) (Dal' 2003, 2, p. 52). Most Russian scholars who have written on the topic of pravda and istina have noted the difference between the mundane and ethical nature of pravda and the sublime and even divine nature of istina: "everyone has his/her own pravda, while istina is one for everybody." Hence, pravda implies subjectivity or inter-subjectivity, while istina refers to absolute reality (Uspensky 1994, p. 190; Arutiunova 1995, p. 7-16; and Lishaev 2006, p. 176-184). Thus, pravda contains an additional semantic connotation absent in the English "truth": it means "(inter-)subjective opinion about something" and sometimes is even translated as "subjective truth" (Lishaev 2006, p. 186).

In the expression of "artistic truth" the word pravda is used, suggesting the subjective nature of khudozhestvennaia pravda and its only partial correspondence to reality. From the 1860s on in Russian art criticism, the term khudozhestvennaia pravda was omnipresent in discussions about new literature, music of the Kuchka, and paintings of Wanderers (Peredvizhniki). Russian writers, artists, and philosophers such as Fyodor Dostoyevsky, Ivan Goncharov, Vladimir Stasov, Konstantin Stanislavsky, and Nikolai Berdyaev, all addressed the concept of "artistic truth" and offered various ways of its attainment in the arts. Dostoyevsky opposed the notion of "artistic truth," which he often interchanged with the concept of "poetic truth," to "truth of real life" or "reality." The writer believed that the purpose of art was not to reflect exactly the incidents of everyday life, but to reflect their "general idea, that is keenly intuited and perfectly captured from the entire multiplicity of homogenous life events" (Dostoyevsky 1972-1990, 21, p. 82). So "artistic truth," according to Dostoyevsky, assumes a complete penetration into the essence of a phenomenon, rather than an exact reflection of it; the scrupulous or photographic copying of reality destroys the "height of the artistic truth" (ibid., 19, p. 154). Goncharov also believed that "artistic truth" is not an ascertaining of facts, but rather some facts reflected in creative imagination:

17 On the philosophical, aesthetic, and hermeneutical matrix of Western European interpretations of "artistic truth," see Zuidervaart 2004. 
The scholar does not create anything, but rather discovers a truth that is waiting yet hidden in the real world. In contrast, the artist creates a likeness of truth, that is, a truth that is observed by him is reflected in his imagination and he transfers these reflections into his artistic production. The result is artistic truth. Consequently, artistic truth and the truth of real life are not the same thing. Place together two or three facts from life just as they happened, and the result comes out as untrue, indeed, as not even plausible (Goncharov 1955, p. 106).

The application of the concept of "artistic truth" in music suggests that music does not have to accurately reflect real events or imitate a particular time, place, and/ or people; rather, it has to reflect our perception of reality and meet our multidimensional expectation of truth. From the 1880s on, the concept of "artistic truth" was no longer related to the representation of daily life. As Olga Haldey points out, "the emphasis had shifted overwhelmingly from the veracity to the artistry of representation" and "artistic truth" was replaced by "artistic truth," in which the "beautiful prevailed over the real" (Haldey 2010, p. 58).

One early twentieth-century article on Rubinstein's opera Sulamith (1883) sums up neatly what Russian listeners expected from a truly artistic work on oriental subject. Employing notions of "artless," "creativity," "creative fantasy," and "artistic works," Iurii Kudriumov clearly refers to "artistic truth" and provides a list of ingredients that he believes should be present in a piece of art:

Formally, to attain "oriental colour" in music is a very simple affair: add augmented seconds as needed-and the deed is done. But to use such a simple device to create the kind of "orient" that Glinka, Rubinstein, and other composers have done is impossible. One needs creative fantasy of a certain kind. If one possesses this, then... just a simple, artless melody can put you in such a mood that you feel exactly as if you were in a fragrant valley of the Levant... Not only in the sphere of creativity, but also in the sphere of evaluation of artistic works - including musical ones - much depends on the entirety of the impressions received throughout the course of life which are deeply rooted in our spiritual being... along with the entirety of the ideas and inclinations that are bequeathed to each of us by the unending series of preceding generations (Kudriumov 1901, p. 111).

Thus, "artistic works" have to reflect our individual life experience as well as the experience shared by an entire group or community to which we belong (ethnic, national, etc.); they also might comprise any historical, societal, or cultural dimension as well as any visual and/or aural impression. Hence, it is crucial that the truth of an artwork assumes an element of imagination, since it is tied to intersubjective interpretation or experience. As French Orientalist culture presented an important part of nineteenth-century Russian cultural experience, it resonated in Russian music about the Orient and informed the Russian sense of "artistic truth" about it. An analysis of nineteenth-century Russian music with and without oriental subject matter reveals that a great number of musical pieces recycled some French musical devices depicting 
the Orient. Many of the musical devices from David's symphonic ode Le Désertthe piece that was so criticized in the 1840s - were adopted by Russians sometimes without giving any credit to the French composer.

Among the most popular harmonic devices employed by David is a lengthy sustained pedal point that Serov fiercely critiqued for its monotony. Towards the end of the nineteenth-century pedal points became one of the most favourite, indeed ubiquitous, idioms of Russian music representing the Orient and Russia itself. Borodin, for example, used excessive orchestral pedals in his opera Prince Igor (1887) to represent the antagonists to the Russians - the Asian Polovtsy people. However, in another symphonic work, In the Steppes of Central Asia (1880), Borodin employed a sustained pedal throughout the section that presented a Russian theme. A selected list of the most famous examples in which a sustained pedal was used to characterize Russian and non-Russian peoples includes: Balakirev's art song "A Desert" and his Overture on Three Russian Themes (1857-1858); Rimsky-Korsakov's art song "El' i pal'ma" ("The Pine Tree and the Palm"), op. 3, no. 1 (1866); "The Persian Dances" from Mussorgsky's opera Khovanshchina (1972-1880) and "The Old Castle" from his Pictures at an Exhibition (1874); and many other musical pieces. Another part of David's Le Désert - the call to prayer sung by a muezzin - inspired a similar prayer in Rubinstein's oriental opera Feramors (1861-1862), which is based on the same plot as David's opera Lalla-Roukh (1862).

French oriental music thus inspired Russian composers to represent not only the Orient, but also Russia itself. Significantly, some Russian composers were aware of this influence. Rimsky-Korsakov once pointed out that his King Berendey's second cavatina from Snegurochka, or The Snow Maiden (1880-1881), is "undoubtedly influenced" by the "charming song" "Ô Nuit, Ô Belle Nuit" from Félicien David's Le Désert (Yastrebtsev 1985, p. 166). Indeed both vocal excerpts of larger works bear striking similarities. First, both songs are written for tenor and have a similar textual subject, the night. Second, both pieces are in triple meter and share a particular rhythmic pattern in the accompaniment and vocal line (a dotted eighth note followed by two thirty-second notes). Third, the harmonic progression of the opening section of Berendey's cavatina is almost identical to that of David's "Ô Nuit": a tonic pedal played by low strings throughout the section is coloured by subdominant and dominant harmonies (see Figures 5 and 6). And finally, the orchestration of both pieces is also similar: in David's "Ô Nuit" the melody is accompanied by a cello section, interpolated with woodwinds mostly when the voice is silent. In Rimsky-Korsakov's cavatina the melody is also accompanied by a string instrument, viola obbligato solo, and high woodwinds that enter when the vocal line is resting. Even the effect of echo between the voice and the woodwinds from David's symphonic ode was emulated in Rimsky-Korsakov's score (see the last two measures in the example from David's "Ô Nuit" and mm. 13-14 in Rimsky-Korsakov's cavatina). ${ }^{18}$

18 Naturally, some differences are found in the harmonic development and structural plan. The Berendey's cavatina has an ABA structure, while David's aria "Ô Nuit" is written in a form of variation: AA'A". Rimsky-Korsakov's harmonic progression is more chromatic and sophisticated (in the 

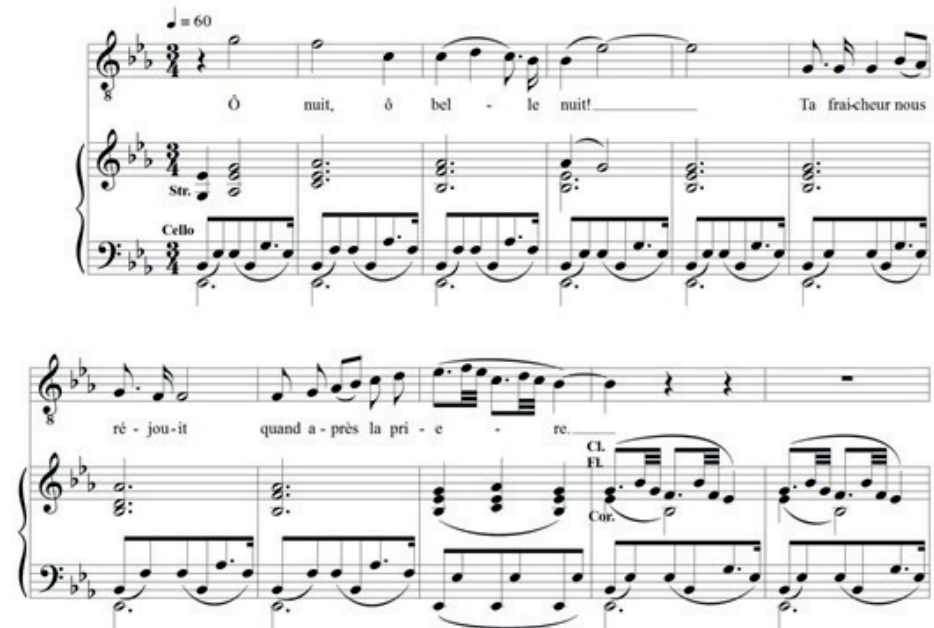

Figure 5: Félicien David, "Ô Nuit, Ô Belle Nuit" from the symphonic ode Le Désert (1844), mm. 28-38.
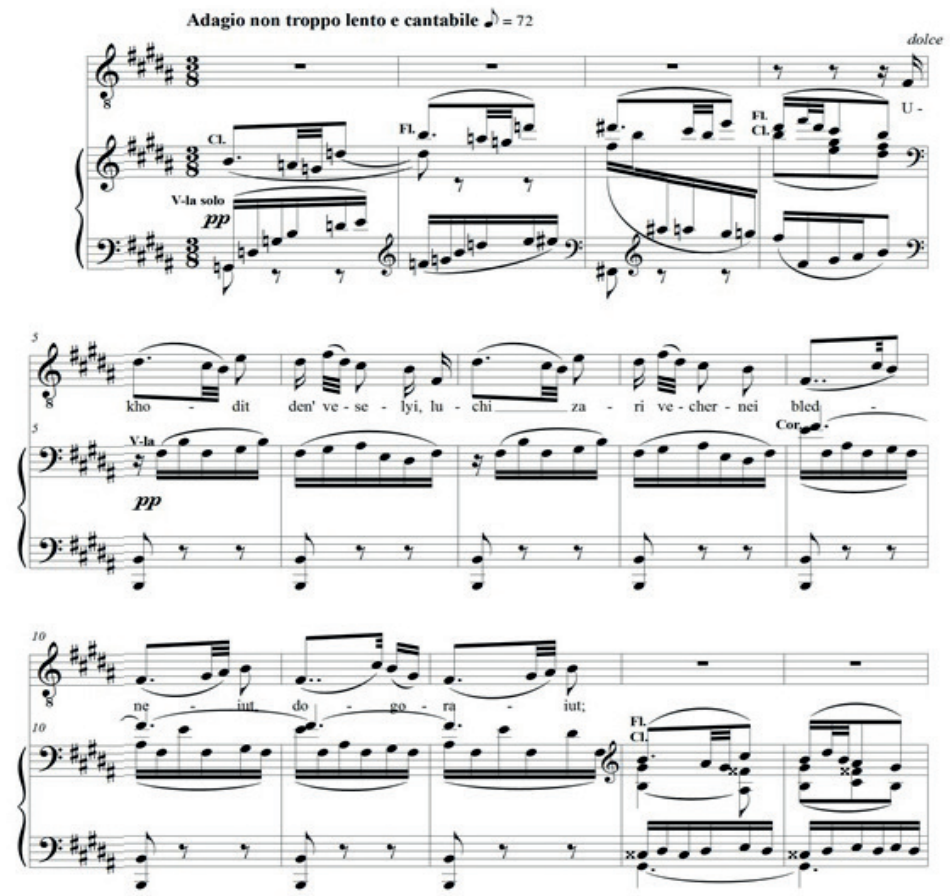

Figure 6: Rimsky-Korsakov, King Berendey's Second Cavatina from Snegurochka (The Snow Maiden) (1880-1881), mm. 1-14.

In My Musical Life (1935), Rimsky-Korsakov recalled that while creating The Snow Maiden he immersed himself into a "pantheistic frame of mind" and "hearkened to the voices of folk creation and of nature" (Rimsky-Korsakov 1935, p. 201). Thus, it 
is particularly striking that despite the opera's subject matter-a Russian fairy tale that evokes Russian pagan rituals and has not the slightest hint of the Orient (except, perhaps, in a general sense of a primitive, non-Christian, society) — Rimsky-Korsakov does not see any contradiction in appropriating musical devices associated with French musical Orientalism. Such identity confusion, in fact, was frequently employed by the composers of Moguchaia kuchka. Rimsky-Korsakov himself recycled his "Zuleika Song" (1882) into an orchestral introduction of Liubava's aria from his opera Sadko (1896), based on a Russian fairy tale. Borodin in his opera Prince Igor (1887) also confused Russian and Eastern musical identities on several occasions; particularly striking is a use of an augmented second in an orchestral and vocal part sung by the principal female Russian character, Yaroslavna (the opening of Yaroslavna's lament from act IV). The members of Balakirev's circle, inspired by Stasov, truly believed in Russia's close historical and cultural relationships with Asia. As Marina Frolova-Walker puts it:

Balakirev did not see the Oriental style as means of representing a separate, alien people, an Other, in current parlance, but as an essential component of musical Russianness... the Oriental style became a default style, so that he ceased to perceive it as Oriental (Frolova-Walker 2007, p. 153).

Frolova-Walker's statement about Balakirev Oriental "default style" can then be applied to at least two other members of his circle.

Besides the members of the Kuchka, other Russian composers also resorted to French musical vocabulary meant to introduce oriental Other to represent the Self. It is probably not a coincidence that Rimsky-Korsakov, in a citation considered earlier, included Tchaikovsky into the Kuchka cohort, since our next example of appropriation of French musical elements, associated with oriental character, is from his Fifth Symphony. In a conversation with Yastrebtsev, Rimsky-Korsakov "praised the Andante from the Fifth Symphony highly, even though the very beginning of it is reminiscent of the well-known aria from Massenet's Le Roi de Lahore" (Yastrebtsev 1985, p. 166). Although Rimsky-Korsakov, did not identify which aria he had in mind, it is known that one of the most favourite arias performed outside the opera in concert halls was Scindia's arioso "Promesse de Mon Avenir" from the fourth act (Finck 1910, p. 188). ${ }^{19}$

Indeed several musical elements suggest that this famous baritone arioso from the opera that Tchaikovsky absolutely adored could have been a point of departure for his Andante. First of all, the beginning of a melody from Tchaikovsky's Andante played by horn (the first five notes) is identical to the beginning of Scindia's arioso: it starts on a tonic, moves in a step-wise motion down to the sixth scale degree, then comes

19 Massenet's opera is set in the eleventh-century India and presents a love triangle plot, in which a priestess Sitâ is loved by Alim, king of Lahore, and Scindia, Alim's minister. Scindia treacherously attacks and kills Alim, but after being in Indra's paradise, Alim is restored to life and sent back to earth. In Act IV, before everyone realizes that Alim has returned, Scindia persuades Sitâ to marry him. In the Arioso "Promesse de Mon Avenir," Scindia turns his thoughts to Sitâ and looks forward to finally possessing her. 
back to the tonic and descends to the seventh scale degree (see Figures 7 and 8). The melodic structure of both excerpts is also similar: each phrase in both works ends with the interval of a falling second. Furthermore, although Tchaikovsky's Andante is written for horn solo, its melody is vocal in nature and fits within the baritone's range, so it could have been the basis for a great operatic aria or arioso.

In addition to melodic similarity, the accompaniment of Tchaikovsky's Andante, like Massenet's arioso, is performed by strings playing simple chord progressions in four-voice chorale-like texture. The harmonic progression of the beginning of Tchaikovsky's second movement could also have been prompted by Massenet. A characteristic establishment of a tonic through a dominant $4 / 3$ chord and tonicization of (or brief modulation to) the third scale degree are found in both pieces. Finally, the tempo and expression markings are similar: the beginning of Tchaikovsky's piece is indicated as Andante cantabile, con alcuna licenza, while Massenet's marking is Andante molto sostenuto cantabile.

Despite all the similarities, a couple of features distinguish Massenet's piece from Tchaikovsky's: a repetitive rhythmical pattern in the vocal line (seven sixteenths followed by a quarter or two eighth-notes) and a wandering harmonic progression. After establishing the G-flat major tonic, the harmony becomes suddenly mobile and tonicizes first the minor sixth, then the dominant, and then the chromatic major third scale degree (moving from G-flat major, though E-flat minor and D-flat major, to B-flat major, instead of diatonic B-flat minor). The harmony thus shifts from diatonic (minor sixth and major dominant) to chromatic (major third) and does so at a significantly fast pace (e.g., in m. 6, the harmony changes every beat). Undoubtedly, Massenet, by creating such an unusual harmonic language, aimed to make Scindia's part sound more exotic to suggest otherness of his character. Tchaikovsky also employs chromatic major third harmony (F-sharp major in the D major tonic), but he uses it as a main key for an entire section with a new theme (con moto), thus again referencing Massenet. Furthermore, this movement offers a number of other features which are listed in Ralph Locke's Musical Exoticism as elements suggesting Oriental/exotic otherness: long-held pedal tone in the accompaniment (the middle part of the movement, Moderato con anima), melismatic solo instrumental lines (middle part and recapitulation), and chromatic passing notes (Locke 2009, p. 51-54). Tchaikovsky's evocation of otherness could have insinuated his own condition of being different and having a queer identity in a complex situation during an intensely homophobic era and society. ${ }^{20}$ The theme of "fate" that violently intrudes upon the Andante's idyllic aura in this case could be interpreted as a repressive external force of society exercising tremendous pressure on anything that goes against its norms. But this statement brings us to a different domain of exoticism - that of gender and sexuality, which would entail separate study and a different set of questions.

20 On musical Orientalism and queer identity, see Boone (1995), Cooke (1998) and Brett (1994, 2009). On Tchaikovsky's music and queer identity, see Orlova (1990), Poznansky (1988, 1998), David Brown (1992), Taruskin (1995), Jackson (1995), Malcolm Brown (2002) and Knapp (2003). 


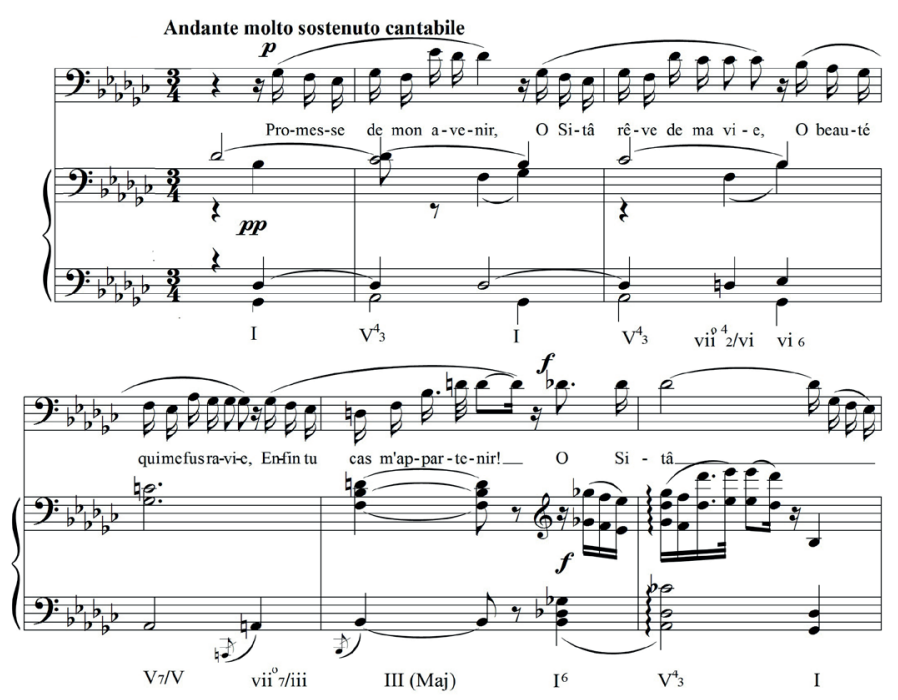

Figure 7: Scindia's arioso "Promesse de Mon Avenir" from Massenet's Le Roi de Lahore (1876), mm. 4-9.

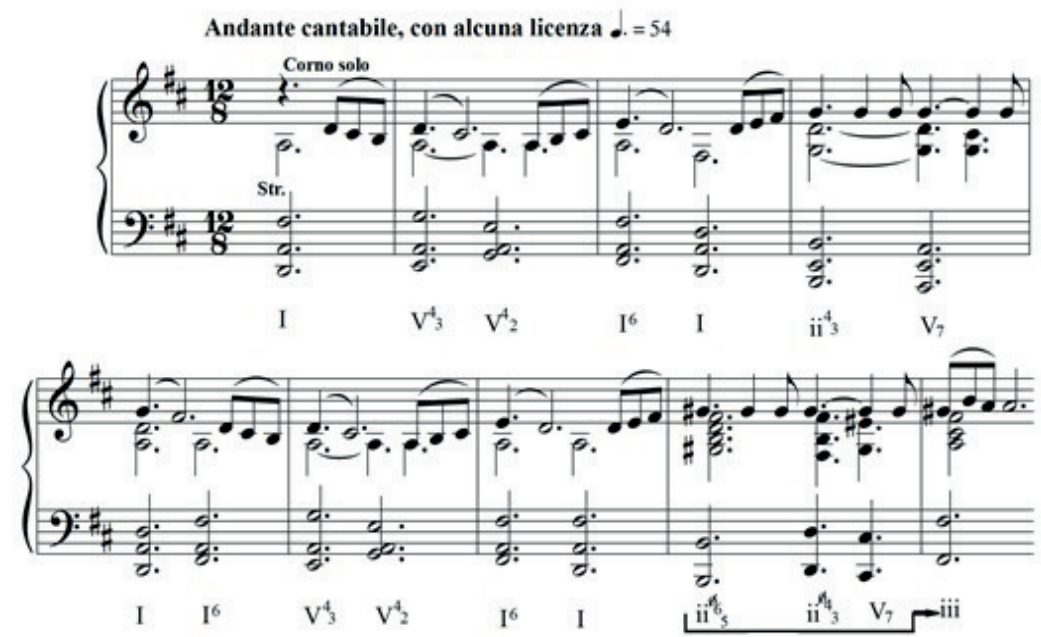

Figure 8: Pyotr Tchaikovsky, Andante from the Symphony No. 5 in E minor, op. 64 (1888), mm. 8-16.

\section{CONCLUSION}

French Orientalist culture resonated in Russia through a wide range of attitudes, and cultural and musical responses. The analysis of Berendey's cavatina from Rimsky-Korsakov's The Snow Maiden and the Andante of Tchaikovsky's Fifth Symphony demonstrates that Russian composers were particularly inclined towards French music with oriental subjects and sometimes even appropriated certain musical elements to represent Russia itself. It is important to recognize that Russia's appeal to musical Orientalism is not actually that surprising given that many members of Russian society (including Stasov, Balakirev, and his Mighty Five circle) considered an oriental character to be an essential part of Russian musical identity. Paradoxically, despite living in close proximity with Asia, few nineteenth-century Russian 
composers neither explored nor made any use of musical samples from their own Orient. Instead they borrowed exciting European (including French) musical clichés. Significantly, many musicians considered such an appropriation perfectly legitimate as the Russian notion of "artistic truth" about the Orient comprised and was shaped by an array of impressions of French Orientalist culture and art. Thus, even though Russian composers often critiqued French musical Orientalism in writing, in practice they borrowed, imitated, and appropriated a number of elements from French music representing the Orient and used them to create their own Russian musical representation, which in turn served as catalyst for musical Russophilia in France at the beginning of the twentieth century.

\section{BIBLIOGRAPHY}

Arutiunova, Nina D. (1995), Istina i etika. Logicheskii analiz iazyka. Istina i istinnost'v kul'ture i iazyke, Moscow, Nauka, p. 7-23.

Bartol'd, Vasily Vladimirovich (1925), Istoriia izucheniia Vostoka v Evrope i Rossii. Lektsii chitannye v universitete i v leningradskom institute zhivykh vostochnykh iazykov, Leningrad, Tov. Alekseeva.

Bellow, Juliet (2013), Modernism on Stage. The Ballets Russes and the Parisian Avant-Garde, Burlington, Ashgate.

Boone, Joseph Allen (1995), "Vacation Cruises; or, the Homoerotics of Orientalism," PMLA, vol. 110, $\mathrm{n}^{\circ}$ 1, p. 89-107. Available online: https://unrulycrossings.wikispaces.com/file/view/Boone Vacation+Cruises .pdf, accessed January 20, 2016.

Brett, Philip (1994), "Eros and Orientalism in Britten's Operas," in Elizabeth W. Brett and Gary C. Thomas (eds.), Queering the Pitch. The New Gay and Lesbian Musicology, New York, Routledge, p. 235-256.

Brett, Philip (2009), "Queer Musical Orientalism," ECHO, vol. 9, no 1, http://www.echo.ucla.edu/ Volume9-Issue1/brett/brett1.html, accessed November 15, 2015.

Brown, David (1992), Tchaikovsky. The Final Years, 1885-1893, New York, Norton.

Brown, Malcolm Hamrick (2002), "Tchaikovsky and His Music in Anglo-American Criticism, 1890s-1950s," in Sophie Fuller and Lloyd Whitesell (eds.), Queer Episodes in Music and Modern Identity, Urbana, University of Illinois Press, p. 134-149.

Chernysheva, Maria (2014), “'The Russian Gérôme?' Vereshchagin as a Painter of Turkestan,” RIHA Journal, $\mathrm{n}^{\circ}$ 96, http://www.riha-journal.org/articles/2014/2014-jul-sep/chernyshevavereshchagin, accessed April 25, 2015.

Christianowitsch, Alexandre (1863), Esquisse historique de la musique arabe aux temps anciens avec dessins d'instruments et 40 mélodies notées et harmonisées par Christianowitsch, Cologne, Librairie du M. Dumont Schauberg. Available online: http://gallica.bnf.fr/ark:/12148/ bpt6k6209485z, accessed January 20, 2016.

Cooke, Mervyn (1998), “'The East in the West.' Evocations of the Gamelan in Western Music," in Jonathan Bellman (ed.), The Exotic in Western Music, Boston, Northeastern University Press, p. 259280.

Cui, Cesar (1952), Izbrannye stati'i, Leningrad, Gos.Muz.Izdat.

Dal', Vladimir I. (2003), Tolkovyi slovar' zhivogo russkogo iazyka v 4 tomakh, Moscow, Russkii iaykMedia.

Dargomyzhsky, Alexander (1952), Izbrannye pis'ma, Moscow, Muzgiz. 
Davis, Mary E. (2010), Ballets Russes Style. Diaghilev's Dancers and Paris Fashion, London, Reaktion Books.

Dostoyevsky, Fyodor (1972-1990), Polnoe sobranie sochinenii v 30 tomakh, Leningrad, Nauka.

Finck, Henry T. (1910), Massenet and His Operas, New York, John Lane Co.

Frolova-Walker, Marina (2007), Russian Music and Nationalism. From Glinka to Stalin, New Haven and London, Yale University Press.

Garafola, Lynn (1989), Diaghilev's Ballets Russes, New York, NY, Oxford University Press.

Garafola, Lynn, and Nancy van Norman Baer (eds.) (1999), The Ballets Russes and Its World, New Haven, CT, Yale University Press.

Goncharov, Ivan A. (1955), "Luchshe pozdno chem nikogda. (Kriticheskie zametki)," in Sobranie sochnenii v vos'mi tomakh, "8. Stat'I, zametki, retsenzii, avtobiografii, izbrannye pis'ma," Moscow,: Gos. izd-vo khudozh. lit.-ry, p. 64-113.

Gordeeva, Evgeniia (1985), Kompozitory “Moguchei kuchki," Moscow, Muzyka.

Haldey, Olga (2010), Mamontov's Private Opera. The Search for Modernism in Russian Theater, Bloomington, Indiana University Press.

Issiyeva, Adalyat (2013), "Russian Orientalism. From Ethnography to Art Song in NineteenthCentury Music," PhD Dissertation, McGill University, Montreal, http://digitool.library.mcgill. ca/webclient/StreamGate?folder id=0\&dvs $=1454341463298 \sim 773$, accessed December 23, 2015.

Jackson, Timothy L. (1995), "Aspects of Sexuality and Structure in the Later Symphonies of Tchaikovsky," Music Analysis, vol. 14, nº 1, p. 3-25.

Jefimoff, Demetrio (1838), Brevi cenni sull'Architettura egiziana, Roma, Con permesso de'superiori.

Jourdain, Amable (1815), "O iazyke persidskom i slovestnosti," Vestnik Evropy, vol. 81, n 9, p. 28-38; vol. $82, \mathrm{n}^{\circ} 15$, p. $168-174$.

Karlinsky, Simon (1990), "Russia's Gay Literature and Culture. The Impact of the October Revolution," in Martin. B. Duberman et al. (eds.), Hidden from History. Reclaiming the Gay and Lesbian Past, New York, NY, NAL Books, p. 347-364.

Kim, Georgii F., and Petr M. Shastitko (eds.) (1990), Istoriia Otechestvennogo Vostokovedeniia Do Serediny XIX Veka, Moscow, Nauka.

Knapp, Raymond (2003), "Passing — and Failing — in Late Nineteenth-Century Russia; or Why We Should Care about the Cuts in Tchaikovsky's Violin Concerto," 19th-Century Music, vol. 26, n 3, p. $195-234$.

Kondrat'eva, Iu. G. (ed.) (1985), Vzaimosviazi russkoi i frantsuzskoi literatur. Ukazatel' knig i statei na russkom iazyke za 1961-1983 gg., Moscow, Gos. Bibl. Im. Lenina.

Kudriumov, Iurii (1901), “'Sulamit' A.G. Rubinsteina," Russkaia muzykal’naia gazeta, vol. 4, p. 109114.

Lebedev, Andrei K. (1972), Vasilii Vasil'evich Vereshchagin. Zhizn' i tvorchestvo 1842-1904, Moscow, Iskusstvo.

Lishaev, Sergei A. (2006), "'Pravda' i 'istina' (iazykovaia kontseptualizatsiia i tematicheskoe svoeobrazie russkoi filosofii)," Vestnik Samarskoi gumanitarnoi akademii. Seriia "Filosofiia. Filologiia," $\mathrm{n}^{\circ} 1(4)$, p. 173-209.

Locke, Ralph P. (2009), Musical Exoticism. Images and Reflections, Cambridge, Cambridge University Press.

Orlova, Alexandra (1990), Tchaikovsky. A Self-Portrait, trans. R.M. Davison, New York, NY, Oxford University.

Petrova, Evgeniia N. (ed.) (2002), Nataliia Goncharova. Gody v Rossii, Saint Petersburg, Palace Editions. 
Poznansky, Alexander (1988), "Tchaikovsky's Suicide. Myth and Reality," 19th-Century Music, vol. 11, $\mathrm{n}^{\circ}$ 3, p. 199-220.

Poznansky, Alexander (1998), “Tchaikovsky. A Life Reconsidered,” in Leslie Kearney (ed.), Tchaikovsky and His World, Princeton, Princeton University Press, p. 3-54.

Rimsky-Korsakov, Nikolai (1935), My Musical Life, trans. Judah A. Joffe, New York, NY, Tudor Publishing Co.

Rosenthal, Bernice Glatzer (ed.) (1997), The Occult in Russian and Soviet Culture, Ithaca, NY, Cornell University Press.

S-ii (1825), "Egipetskie drevnosti v St. Peterburge", Severnaia pchela, vol. 9, p. 3.

Said, Edward (1978), Orientalism, New York, NY, Vintage Books.

Salvador-Daniel, Francisco (1865), Album de douze chansons Arabes, Mauresques et Kabyles, Paris, S. Richault et Cie Editeurs.

Schaeffner, André (1953), "Debussy et ses rapports avec la musique russe," in Pierre Souvtchinsky (ed.), La musique russe, vol. 1, Paris, Presses Universitaires de France, p. 95-138.

Schimmelpenninck van der Oye, David (2009), "Vasilij V. Vereshchagin's Canvases of Central Asian Conquest," Cahiers d'Asie centrale, $\mathrm{n}^{\circ}$ 17/18, p. 179-209. Available online: http://asiecentrale.revues.org/1196, accessed December 23, 2015.

Serov, Alexander (1892), Kriticheskie stat'I, Saint Petersburg, tip. Depart. Udela.

Serov, Alexander (1962), Muzykal'noe nasledstvo, Moscow, Muzgiz.

Serov, Alexander (1987), Stat'i o muzyke, Moscow, Muzyka.

Sismondi, Simon de (1818), "O literature Arabov," Vestnik Evropy, vol. 102, n 23, p. 175-216.

Solkin, Victor V. (ed.) (2005), Peterburgskie sfinksy. Solntse Egipta na beregakh Nevy, Saint Petersburg, Izd. Zhurnal "Neva."

Stasov, Vladimir (1894), Sobranie sochinenii V.V. Stasova 1847-1886, Saint Petersburg, tip. Stasiulevicha.

Struiskii, Dmitrii (1840), "O egipetskoi arkhitekture i trudakh arkhitektora D. Efimova," Otechestvennye zapiski, vol. 11, Smes', p. 30-34.

Struve, Vasily V. (1912), Peterburgskie sfinksy, Saint Petersburg, tip. M.A. Alexandrov.

Swift, Mary Grace (1974), A Loftier Flight. The Life and Accomplishments of Charles-Louis Didelot, Balletmaster, Middletown, Conn., Wesleyan University Press.

Taruskin, Richard (1995), "Pathetic Symphonist," New Republic (6 February), p. 26-40.

Tchaikovsky, Pyotr (1934-1936), Perepiska s N.F. von Meck, ed. V. A. Zhdanov and N.T. Zhegin, 3 vols, Moscow, Academia.

Tchaikovsky, Pyotr (1955), Pis'ma k blizkim, Moscow, Muz. Izdat.

Tchaikovsky, Pyotr (1959-1971), Polnoe sobranie sochinenii. Literaturnye proizvedniia i perepiska, ed. B.V. Asaf'ev, 18 vols, Moscow, Izdatel'stvo Muzyka.

Uspensky, Boris A. (1994), Kratkii ocherk istorii ruskogo literaturnogo jazyka (XI-XIX veka), Moscow, Gnosis.

Weiss, Piero, and Richard Taruskin (eds.) (1984), Music in the Western World. A History in Documents, New York, Schirmer Books.

Yastrebtsev, Vasilii (1985), Reminiscences of Rimsky-Korsakov, ed. and trans. Florence Jonas, New York, Columbia University Press.

Zuidervaart, Lambert (2004), Artistic Truth. Aesthetics, Discourse, and Imaginative Disclosure, Cambridge, Cambridge University Press. 